\title{
CRUZ, Gastão. As pedras negras. Lisboa: Relógio d'água, 1995.
}

Edgard Pereira Universidade Federal do Minas Gerais

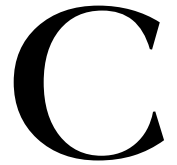

omo é sabido, Gastão Cruz fez parte de coletiva que reuniu, além dele, Fiama H. Pais Brandão, Casimiro de Brito, Maria Teresa Horta e Luiza Neto Jorge em torno de um projeto polêmico de valorização da fragmentação sintática e de distanciamento do sujeito na poesia. O poema buscava em si mesmo uma densidade significativa, cujos suportes se firmavam ora numa estrutura rígida de auto-referência, ora numa rede de ressonâncias contextuais. Uma das heranças dessa aprendizagem estética consistiu precisamente no desenvolvimento de uma forte lucidez crítica diante dos excessos confessionais. Se em Campânula (1978) o compromisso metalingüístico é fundamental, gerando uma notável reflexão sobre os limites o os modos de organização da linguagem poética, a partir de Órgão de luzes (1981), desenvolve um percurso temático revelador de um certo afastamento do espaço público ou teórico, desaguando no domínio do próprio sujeito, com ênfase e acento nos desdobramentos da alteridade e da sexualidade. Autor de mais de 15 livros de poesia, um dos mais importantes poetas em atividade em Portugal, com uma trajetória fundada na coerência e no rigor, Gastão Cruz é também um competente crítico de literatura, tendo publicado em 1973 uma obra fundamental para o estudo da poesia portuguesa contemporânea - $A$ poesia portuguesa boje.

Com As pedras negras, estamos diante de uma poética extremamente sofisticada e contida, em que a perturbadora obscuridade se torna um constante desafio. A brevidade dos poemas, a simplicidade dos títulos, em muitos casos retomando o diálogo cultural, não conseguem camuflar um sentido cada vez mais fugidio e disperso. Práticas poéticas como esta elegem 
seus leitores preferenciais - aqueles que a elas se entregam na perspectiva consciente de um entendimento facultado ao fim de um longo processo de concentração: "a idade lerá/ sobre um longo silêncio a palavra" (p.17). Uma visão de conjunto perceberá uma vasta constelação de motivos ou núcleos (embora não haja subdivisões explícitas) que se repetem de três a cinco vezes, de forma alternada e intensa: a série das cidades, geradora de amplas irradiações, iniciase no segundo poema, de forma quase programática: "Ah, o olhar viaja/ nessas câmaras frágeis/ que interrogam o brilho das cidades" ( $p$. 10), agrupando cinco poemas: "Outubro", no qual lemos o fragmento há pouco citado, seguido de "Sons", em que os vetores urbanos adquirem um contorno vago - "Os sons passam ao longe/no seu interior como noutra cidade" (p.11). O cenário urbano prossegue ainda em mais três textos, desenhando o amplo espectro da representação sejam as "Grandes cidades afogadas em fumo...", mencionadas em "Cidades" (p.12) ou o ceticismo de "Não se pode escolher para o silêncio/ uma cidade ouvida quando os dias...", em "Nosso tempo" (p.13), retornando um pouco adiante: "A cidade// voltará a chamar-me..." (p.17).
Sucedem-se outras séries, entre elas, a da poesia, a da casa, a do mar, a do tempo, a do espelho, a das margens, mas, sobretudo e de forma celebratória ou ritualística, a da morte com suas "estrelas de sombra", seus corpos enevoados e em chamas: "em chamas/ era o corpo da tarde celebrado" (p.23); "não me detenhas/ enquanto o corpo eterno / arde na tarde" (p.24). O trabalho de luto (a dedicatória "à memória do Carlos Fernando", a tarja e os signos negros da capa) retorna com uma intensidade de prece ou de escrita desesperada diante das oxidações operadas pelo tempo, as diversas formas de erosão com que somos obrigados a conviver: "Mas $\mathrm{O} /$ rosto sem luz vence-te/ como se a vida visses com os olhos/ da face enevoada" (p.56). Os poemas elegíacos atingem uma altitude e intensidade emotiva raras vezes lida na literatura contemporânea, configurando a idéia desconcertante da permanência da fantasia colorida do sonho e da criação, mesmo em face da corrosão do ar calcinado dos motores e da inevitável oxidação gelada das células, como no belíssimo poema "No mar", um dos mais longos do livro:

Quereriam ouvir-te respirar, mundo mudado, os que no mar excêntrico 
soltam braços, lembrados de que o ar não os pode salvar Mas é idêntico ao ar o mar sem centro, figura

que fulgura fora do teu corpo de mármore, lavrado pelo tempo, mundo a que não pertencem os náufragos amados e um dia perdidos nesse líquido frio indivisível Se pudessem ouvir

o teu sopro, seriam devolvidos aos veios do visível divisível? As estrelas de sombra desfazendo um céu sem falhas deixariam cair sobre eles de novo a sua cinza (p.36)

O que se perde em formas ganha-se em eternidade, o corpo perdido torna-se único e definitivo através da morte, esta talvez seja outra possibilidade sugerida pela ausência de pontuação e imediata intersecção de planos sintagmáticos, anulando espaços entre o "líquido frio indivisível" da palavra e "os veios do visível divisível" da emoção. Paralela à extensa reflexão sobre o tempo e a morte, a escrita poética de Gastão Cruz instala mais a hesitação e a alternativa do que a pergunta e a dúvida, estabelecendo contigüidade entre os poemas, forçando a flutuação e contaminação dos sentidos. Como afirma Eduardo Prado Coelho: "O que define o livro Pedras negras é o facto de que o indialectizável cresce, o deserto cresce, o não-tempo cresce, a morte avança sobre os lugares da vida. Há uma luta entre "o líquido frio indivisível" e "os veios do visível divisível". (O cálculo das sombras. Porto: Asa, 1997, p.362)

Como se tratasse de estrutura explodindo sobre si mesma, retomando traços expressivos da poesia 61 , o sujeito de enunciação, entretanto, reaparece, ainda que deixando uma suspeição a respeito da poesia como confidência: "Nada nos desconhece como a arte/ o que nos dizem sobre os sentimentos/ essas frases?" (p.25). Ao longo de todo o livro, sucedem-se, estilhaçadas, as reflexões sobre a incoerência do sistema em que se assenta a ordem das coisas, o camoniano desconcerto do mundo, percebido por um olhar cético, hesitante entre a escuridão do mundo individual e o brilho enganador das cidades que engendra a elaboração salvadora de quimeras: "... A cidade// voltará a chamar-me" (p.17). Ainda que nos espaços calcinados permaneça o brado para o qual não existe solução: "Estamos vivos e já não temos tempo" (p. 37). 